Check for updates

Montreal

Cite this as: $B M J 2020 ; 371: m 4975$ http://dx.doi.org/10.1136/bmj.m4975 Published: 31 December 2020

\title{
Covid-19: Russia admits to understating deaths by more than two thirds
}

\section{Owen Dyer}

Russia's true death toll from the novel coronavirus pandemic is not about 57 ooo, as official figures claim, but more than 180 ooo, the country's deputy prime minister, Tatiana Golikova, conceded at a press conference.

Russia's claims of an extraordinarily low mortality have been widely dismissed as implausible for months by foreign observers and Russian doctors alike. Every other indicator, from packed hospitals with long lines of ambulances to mortality among health workers documented by their own associations, has painted a picture of a country hit hard by the pandemic, not one miraculously spared.

These suspicions were confirmed when the Rosstat statistics agency said on 28 December that the number of deaths from all causes recorded between January and November was 229700 higher than in 2019. "More than $81 \%$ of this increase in mortality over this period is due to covid," said Golikova. That would mean that more than 186 ooo Russians have died from covid-19.

The figures mean Russia ranks third in the world in terms of deaths from covid-19, behind only the US and Brazil. It would also give Russia the fourth highest per capita death rate, about 1273 deaths per million population, behind only San Marino, Belgium, and Slovenia.

But the higher figures, which are estimated from numbers of excess deaths, may never find their way into official statistics of the pandemic. The director of Mexico's National Centre for Preventive Programs and Disease Control made a similar announcement in October, telling a press conference that the country had undercounted deaths by more than 50 ooo. In that case the new estimate was based on individual review of death certificates-yet the extra deaths have never been added to Mexico's official count. ${ }^{1}$

A wide discrepancy between Russian cities' accurate counts of deaths from all causes and the official national covid-19 mortality figures has been evident since the beginning of the pandemic. ${ }^{2}$ The low official figure was generated by only reporting deaths in which novel coronavirus infection was identified on autopsy.

From the beginning the official numbers drew widespread scorn from Russian doctors, who on social media painted a far grimmer picture, often mourning deaths in their own ranks from lack of personal protective equipment. A privately maintained list of Russian medical staff who lost their lives fighting the pandemic now stands at over 1000 names. ${ }^{3}$
Three doctors who raised concerns about the country's response mysteriously fell from windows in the early months of the pandemic. ${ }^{4}$ Anastasia Vasilyeva, the head of the doctors' union Alyans Vrachei (Doctors' Alliance), an opposition linked group that has criticised pandemic preparations, was arrested and beaten by police when she attempted to deliver PPE to a hospital near Novgorod. ${ }^{5}$

The deputy prime minister's admission will embarrass President Vladimir Putin, who has favourably compared Russia's response to those of other countries, on the basis of its supposed low death rate. Putin later appeared somewhat chastened, telling regional governors in one televised meeting in May that "we don't have much to brag about."

But the imminent prospect of mass immunisation with Russia's Sputnik vaccine has recently seen Putin again touting his country's response, even as he personally adopts a wary attitude to the virus. He has spent much of the past year secluded at his dacha outside Moscow, and visitors to the president must first walk through a specially constructed corridor in which they are sprayed from all sides with disinfectant.

Dyer O. Covid-19: Mexico acknowledges 50000 more deaths than official figures show. BMJ 2020;371:m4182.

doi: 10.1136/bmj.m4182 pmid: 33122250

2 Bonch-Osmolovskaya K, Schennikov A, Martynova E. Unaccounted for: Real mortality from covid-2019 in Moscow is almost 3 times higher than official figures. Novaya Gazeta. 11 May 2020. https://novayagazeta.ru/articles/2020/05/11/85324-neuchtennye.

3 Memory list [in Russian]. https://sites.google.com/view/covid-memory/home.

$4 \quad$ Khurshudyan I. Three Russian doctors have fallen from hospital windows in two weeks, amid reports of dire conditions. Washington Post. 6 May 2020. https://www.washingtonpost.com/world/europe/three-russiandoctors-have-fallen-from-hospital-windows-in-two-weeks-amid-reportsof-dire-conditions/2020/05/06/c3ca73f4-8f88-11ea-a9c073b93422d691_story.html.

5 Russia: Authorities detain doctor who exposed flaws in covid-19 response. Amnesty International. 3 Apr 2020. https://www.amnesty.org/en/latest/news/2020/04/russia-authorities-detain-doctor-who-exposed-flawsin-covid19-response.

This article is made freely available for use in accordance with BMJ's website terms and conditions for the duration of the covid-19 pandemic or until otherwise determined by BMJ. You may use, download and print the article for any lawful, non-commercial purpose (including text and data mining) provided that all copyright notices and trade marks are retained. 